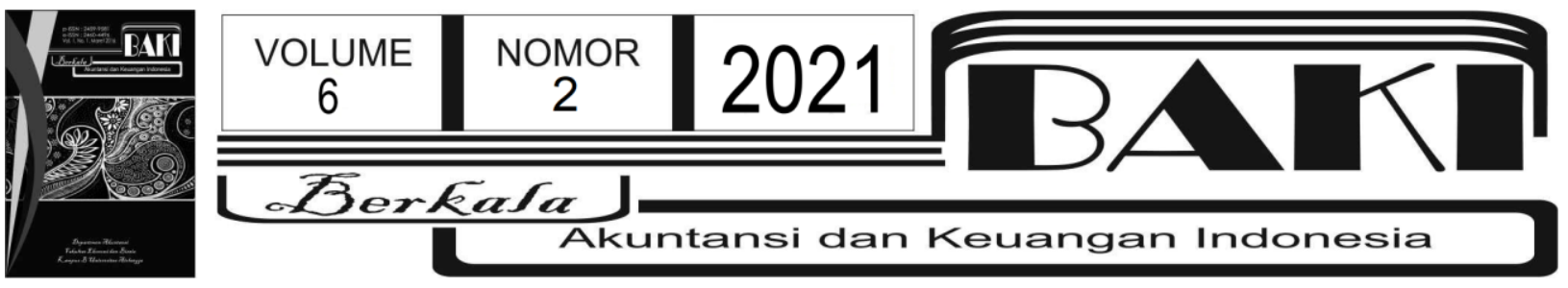

\title{
DETERMINANTS OF AGRICULTURAL CORPORATE CSR DISCLOSURE ON BEI
}

\section{DETERMINAN TERHADAP PENGUNGKAPAN CSR PERUSAHAAN PERTANIAN DI BEI}

\section{Veronika Enggarsih ${ }^{1 *}$, Arif Nugroho Rachman ${ }^{2}$}

1,2Sekolah Tinggi Ilmu Ekonomi Surakarta

* corresponding author : veronickae@gmail.com

\begin{tabular}{l} 
IN F O A R T I K E L \\
\hline Histori Artikel: \\
Tanggal Masuk 17 Februari 2021 \\
Revisi Diterima 24 Maret 2021 \\
Tanggal Diterima 30 Agustus \\
2021 \\
Tersedia Online 6 September \\
2021
\end{tabular}

Keywords: , CSR disclosure, leverage, media exposure, profitability

Kata Kunci: profitabilitas, pengungkapan CSR, media exposure, leverage

\section{A B S TR ACT}

This study aims to determine the effect of profitability, leverage, and media exposure on CSR in agricultural companies listed on the IDX in 2015 - 2019. Sampling using purposive sampling technique as many as 15 companies with a span of time observations made for 5 years and selected as many as 75 objects of observation. The data analysis technique used multiple linear regression analysis with the help of the SPSS program. The results of this study indicate that profitability does not affect CSR disclosure, leverage does not affect CSR disclosure, while media exposure affects CSR disclosure.

A B STRAK

Penelitian ini bertujuan untuk mengetahui pengaruh profitabilitas, leverage, dan media exposure terhadap CSR pada perusahaan pertanian yang tercatat di BEI tahun 2015 - 2019. Pengambilan sampel menggunakan teknik purposive sampling sebanyak 15 perusahaan dengan rentang waktu pengamatan yang dilakukan selama 5 tahun dan terpilih sebanyak 75 objek pengamatan. Teknik analisis data menggunakan analisis regresi linear berganda dengan bantuan program SPSS. Hasil penelitian ini menunjukan bahwa profitabilitas tidak mempengaruhi pengungkapan CSR, leverage tidak mempengaruhi pengungkapan CSR, sedangkan media exposure mempengaruhi pengungkapan CSR.

Berkala Akuntansi dan Keuangan Indonesia p-ISSN: 2459-9581; e-ISSN 2460-4496 DOI: 10.20473/baki.v6i2.25504

Open access under Creative Common Attribution-Non Commercial-Share A like 4.0 International Licence (CC-BY-NC-SA) @(1) (9) 


\section{Pendahuluan}

Meningkatkan nilai perusahaan merupakan salah satu tujuan atau fokus utama yang diinginkan oleh suatu industri. Nilai perusahaan dapat ditingkatkan dengan cara memberikan kepuasan terhadap stakeholder dan menjalin hubungan baik terhadap masyarakat serta karyawan. Hubungan yang baik dapat terjalin dengan komunikasi yang terbuka dari perusahaan. Mempublikasikan laporan keuangan merupakan cara perusahaan dapat berkomunikasi kepada stakeholder dan masyarakat. Data yang memberi gambaran terkait keuangan suatu perusahaan dapat dilihat pada laporan keuangan sekaligus dapat dijadikan gambaran kinerja keuangan perusahaan tersebut (Fahmi 2012). Pengungkapan CSR (Corporate social Responsibility) menjadi salah satu cara membangun sebuah value perusahaan agar semakin tinggi. Perusahaan melakukan pengungkapan CSR atau tanggung jawab sosial perusahaan kepada publik melalui laporan tahunan serta sustainability report. Pengungkapan CSR telah diatur dalam Undang-Undang No. 32 tahun 2009 tentang Perlindungan dan Pengelolaan Lingkungan Hidup Pasal 68a yang berisi para pelaku usaha diwajibkan melaporkan perlindungan secara baik dan benar (Undang-Undang 2009) serta Peraturan Pemerintah No. 47 Tahun 2012 tentang tanggung jawab sosial dan lingkungan perseroan terbatas (Peraturan Pemerintah RI 2012).

CSR merupakan perilaku atau kepekaan dan keperdulian untuk ikut serta memberi manfaat terhadap perlindungan lingkungan sosial, menyelesaikan masalah, serta menaikkan taraf hidup masyarakat (Fuad 2017). Pelaksanaan CSR dilakukan untuk mengurangi dampak negatif dari aktivitas operasi perusahaan terhadap lingkungan, maka pengungkapan CSR ini dianggap penting bagi sebagian masyarakat yang terkena dampak dari aktivitas perusahaan. Implementasi CSR sangat memberikan manfaat bagi banyak pihak, selain nama baik yang dapat memberikan citra positif dan dapat meningkatkan nilai pada perusahaan, manfaat juga dirasakan oleh masyarakat dan lingkungan sekitar (Gray, Owen, and Maunders 1988).

Implementasi CSR di Indonesia saat ini masih menjadi masalah tersendiri dalam dunia bisnis, banyak perusahaan tidak melakukan tanggung jawab sosial perusahaan. Pada tahun 2019, Kepala Bagian Perekonomian Sekretariat Daerah Pasaman Barat menyatakan bahwa ada 21 perusahaan sawit besar dan perbankan yang tidak merealisasikan CSR atau tanggung jawab sosial perusahaan (Maulana 2019). Kasus lainnya terjadi, pencemaran sungai terjadi akibat dari pembuangan limbah oleh perusahaan sawit PT. Kallista Alam, PT. Raja Marga dan PT. Socfindo, di sungai seumayam merugikan masyarakat yang tinggal disekitar sungai (Hanafiah 2020). Perusahaan pertanian khususnya perusahaan kelapa sawit menjadi perusahaan yang sering mengalami kasus tidak diterapkannya CSR secara baik berupa perusakan lingkungan, pembukaan lahan secara ilegal berupa penebangan pohon dan pembakaran hutan hingga pembuangan limbah ke sungai marak terjadi. 
Faktor yang dianggap mempengaruhi tinggi rendahnya pengungkapan CSR yakni profitabilitas. Profitabilitas adalah kapasitas perusahaan dalam mendapatkan keuntungan terkait dengan penjualan, total aktiva ataupun modal sendiri (Sartono 2010). Semakin tinggi laba yang dihasikan maka semakin besar pula pelaporan tanggung jawab sosial. Riset mengenai profitabilitas sudah dilakukan oleh (Rofiqoh \& Priyadi 2016), (Hasnia \& Rofingatun 2017) menyatakan bahwa profitabilitas tidak mempengaruhi pengungkapan CSR yang berarti bahwasanya tingkat ketinggian atau kerendahan profitabilitas tidak mempengaruhi tinggi rendahnya pengungkapan CSR, sedangkan pada riset (Ruroh \& Latifah 2018), (Pakpahan \& Lasminta 2018), (Cahya \& Sedana 2019), (Herdi \& Erinos 2020) menyatakan bahwa profitabilitas mempengaruhi pengungkapan CSR.

Faktor lain yang dianggap dapat mempengaruhi pelaporan CSR yakni Leverage. Leverage adalah jumlah utang yang dipergunakan untuk mendanai pembelian aset-aset perusahaan (Fakhrudin 2008). Semakin tinggi nilai leverage suatu perusahaan berarti mengurangi pelaporan CSR. Riset mengenai leverage sudah dilakukan oleh (Herdi \& Erinos 2020) dan menyatakan jika pengungkapan CSR tidak dipengaruhi oleh leverage yang berarti bahwa leverage tidak mempengaruhi pelaporan CSR. Berbeda dengan riset (Rofiqoh \& Priyadi 2016), (Cahya \& Sedana 2019), (Ruroh \& Latifah 2018) yaitu leverage mempengaruhi pengungkapan CSR.

Media Exposure atau pengungkapan media menjadi salah satu cara perusahaan membangun image positif kepada publik. Perusahaan dapat memberikan informasi terkait kegiatan CSR melalui media cetak maupun elektronik. Media cetak yang sering digunakan perusahaan sebagai pengungkapan informasi terkait kegiatan CSR yaitu koran. Media massa atau portal berita menjadi hal paling efektif dalam pengungkapan CSR demi menciptakan image positif didukung dengan semakin banyaknya pengguna internet. Penelitian terkait media exposure sudah dilakukan oleh (Hasnia \& Rofingatun 2017), (Pakpahan \& Lasminta 2018) yang menyatakan bahwa media exposure mempengaruhi pengungkapan CSR. Riset yang sudah dilakukan oleh (Widiastuti dkk., 2018), (Herdi \& Erinos 2020) menyatakan bahwa media explosure tidak mempengaruhi pengungkapan CSR.

Kasus yang terkait penyimpangan CSR oleh perusahaan sawit PT. Kallista Alam dan lainya. Pembuangan limbah tanpa diolah kembali ke sungai akibat aktivitas perusahaan. Hasil dari penelitian diatas menunjukan perbedaan, maka peneliti tertarik melakukan penelitian kembali terkait pengungkapan CSR menggunakan variabel profitabilitas dan leverage. Penelitian (Rofiqoh and Priyadi 2016) menjadi acuan pada penelitian ini dengan menambahkan sebuah variabel baru yaitu media exposure. 


\section{Tinjauan Pustaka}

\subsection{Teori Stakeholder}

Tanggung jawab Perusahaan bukan hanya untuk keinginan kepada para pemiliknya saja, namun perusahaan juga harus bertangung jawab kepada para pemangku kepentingan atau stakeholder guna menilai kinerja suatu perusahaan. Seluruh pihak dalam ataupun luar, meliputi: pemerintah, investor, masyarakat disekitar lingkungan, lembaga yang berada diluar perusahaan, internasional, dan sebagainya disebut Stakeholder (Hadi 2011).

Tanggung jawab sosial diungkapan pada laporan tahunan dan dapat menjadi salah satu upaya agar menumbuhkan kepercayaan kepada para pemangku kepentingan atau stakeholder. Teori stakeholder adalah sebuah konsepsi manajemen strategis yang bertujuan untuk mengembangkan kelebihan kompetitif dan mendukung perusahaan menguatkan hubungan bersama kelompok-kelompok eksternal (Mardikato 2014). Teori ini menuntut perusahaan untuk menggeser tujuan perusahaan dari orientasi terhadap laba kearah pemberian manfaat kepada para stakeholder (Sari 2012).

\subsection{Teori Legitimasi}

Teori Legitimasi pada dasarnya merupakan hubungan saling menguntungkan antara korporasi dengan masyarakat. Perusahaan dituntut untuk menyelaraskan norma sosial yang berlaku serta mendapatkan legitimasi masyarakat dari dampak aktivitas yang ditimbulkan. Teori legitimasi mengemukakan bahwa suatu industri harus selalu meyakinkan masyarakat mengenai aktivitas tempat perusahaan beroperasi sudah dilakukan sejalan dengan norma atau peraturan serta nilai yang berlaku pada lingkungan sosial atau sekitar (Mandaika \& Salim 2015).

Penyampaian informasi kepedulian terhadap masyarakat dapat diungkapkan perusahaan melalui CSR. Teori legitimasi menyatakan bahwa perusahaan harus terus memberikan keyakinan kepada masyarakat akan kinerja dan aktivitasnya dapat diterima oleh lingkungan sosial. Kesan tanggungjawab sosial dapat digambarkan perusahaan melalui laporan keberlanjutan sehingga bisa diterima oleh masyarakat (Wibowo 2014). Legitimasi penting dilakukan agar suatu perusahaan diterima dengan baik oleh masyarakat, maka sejalan dengan tujuan peningkatan nilai perusahaan yang mempunyai pengaruh bagi keberlangsungan suatu perusahaan (Pakpahan \& Lasminta 2018).

\subsection{Teori Keagenan}

Teori keagenan (agency theory) memiliki konsep yaitu sebuah ikatan kontraktual yang terjalin antara prinsipal dan agen (Supriyono 2018). Dimana principal merupakan pemilik perusahaan yang memberikan wewenang kepada agen atau manajemen yang menjalankan tugas. Hubungan princial dengan agen disepakati dengan perjanjian atau kotrak untuk suatu 
tujuan yang sama. Kontrak tersebut berisikan pemecahan tugas dan fungsi antara principal dan agen (Jensen and Mecking 1976). Namun, pemecahan tugas dan fungsi tersebut tersebut menimbulkan banyak konflik.

Asumsi dari teori keagenan menyatakan bahwa setiap perseorangan memiliki keinginan masing-masing, tidak menutup kemungkinan bahwa agen akan bertindak menguntungkan diri sendiri. Pricipal memiliki cara untuk menghindari kemungkinan tersebut dengan memberikan insentif dan kompensasi, dari kegiatan tersebut menimbulkan suatu biaya yang disebut biaya keagenan. Principal juga melakukan monitoring terhadap aktivitas agen. Prespektif teori keagenan menyatakan bahwa laporan tahunan terutama pengungkapan CSR menjadi cara principal mengontrol atau mengamati aktivitas agen atau manajemen (Hasnia \& Rofingatun 2017).

\subsection{Teori Pensignalan}

Teori pensignalan menjelaskan mengapa manajemen perusahaan mau melaporkan infomasi kepada publik tanpa keharusan. Manajemen perusahaan yang mengambil tindakan memberikan arah untuk pemegang saham terkait bagaimana manajemen melihat kemungkinan perusahaan adalah sinyal (Brigham and Houston 2011).

Teori pensignalan menjelaskan alasan suatu perusahaan melakukan pengungkapan informasi yang positif kepada publik. Informasi positif sangat bemanfaat bagi suatu peusahaan untuk membangun citra. Pengumuman informasi akuntansi dapat memberi sinyal bahwa perusahaan memiliki prospek yang baik di masa depan (Sharpe 1997). Upaya perusahaan membagun citra positif salah satunya dengan melaporkan CSR kepada publik.

\subsection{CSR (Corporate social Responsibility)}

CSR (Corporate Social Responsibility) merupakan wujud perhatian perusahaan kepada lingkungan sosial. Tanggung jawab sosial merupakan bagaimana sebuah perusahaan dapat memberikan dampak positif secara luas melalui pengelolaan bisnisnya (Mardikato 2014). Kepedulian perusahaan terhadap lingkungan sosial juga termasuk dalam upaya perusahaan membangun image. Pengungkapan tanggung jawab sosial secara relevan bagi pihak luar akan lebih meningkatkan kepercayaan atau menciptakan legitimasi terhadap tanggung jawab sosial perusahaan. Hal ini sejalan dengan teori pensignalan.

CSR juga merupakan bentuk tanggung jawab perusahaan yang ditujukan kepada stakeholder. Stakeholder adalah para pemangku kepentingan seperti investor. Sesuai dengan teori keagenan, pengungkapan CSR digunakan para stakeholder untuk mengontrol kinerja manajemen. Taggung jawab sosial diungkapan dengan alasan yaitu untuk memahami apakah kinerja sosial perusahaan telah dicapai dengan baik sesuai harapan, mengetahui upaya 
peningkatan kinerja sosial, untuk memahami keterkaitan dari apa yang dilakukan perusahaan tersebut (Sembiring 2005).

Pengungkapan tanggung jawab sosial perusahaan dibedakan menjadi dua, bersifat sukarela (voluntary disclosure) dan wajib (mandatory disclosure). Perusahaan melakukan pengungkapan secara sukarela untuk mendapatkan kepercayaan dari stakeholder meskipun harus mengeluarkan biaya (cost). Pengungkapan CSR bersifat mandatory disclosure dengan adanya Peraturan Undang-Undang No. 32 tahun 2009 tentang Perlindungan dan Pengelolaan Lingkungan Hidup Pasal 68a (Undang-Undang 2009), PSAK No.1 Paragraf 12 Revisi 2012 (Ikatan Akuntansi Indonesia 2012), dan PP No. 47 Tahun 2012 berisi pengungkapan tanggung jawab sosial dimuat pada laporan tahunan perusahaan (Peraturan Pemerintah RI 2012).

\subsection{Profitabilitas}

Kesanggupan perusahaan untuk menghasilkan laba disebut profitabilitas. Profitabilitas menjadi kriteria investor untuk mengambil keputusan investasi terhadap perusahaan tersebut, bagi manajemen profitabilitas menjadi pertimbangan evaluasi terhadap kinerja keuangan. Pengukuran profitabilitas dapat dihitung dengan mengguakan rasio. Rasio profitabilitas digungakan sebagai rasio mengukur kemampuan perusahaan dalam mendapatkan laba. Ukuran tingkat keefektivitasan manajemen sebuah perusahaan dapat dihitung dengan rasio (Kasmir 2014).

Perusahaan yang mempunyai tingkat profitabilitas tinggi akan mendapatkan perhatian yang lebih tinggi dari publik sehingga mendorong kepentingan stakeholder. Berkaitan dengan teori stakeholder, perusahaan akan memberikan suatu kepuasan terhadap stakeholder dengan memenuhi kewajiban berupa tanggung jawab sosial sesuai dengan profit yang telah dihasilkan, maka dari itu tingkat profitabilitas suatu perusahaan tinggi maka ia juga memiliki kewajiban mengungkapkan CSR yang tinggi pula.

Penelitian mengenai pengaruh profitabilitas tehadap pengungkapan CSR telah dilakukan beberapa diantaranya (Ruroh \& Latifah 2018) serta penelitian (Pakpahan \& Lasminta 2018) menyatakan bahwa profitabilitas mempengaruhi pengungkapan CSR sedangkan pada penelitian (Herdi \& Erinos 2020) menyatakan bahwa profitabilitas tidak mempengaruhi pengungkapan CSR. Dari uraian diatas ditemukan perbedaan dari hasil riset terdahulu, bisa disimpulkan hipotesis yaitu:

\section{$H_{1}$ : Profitabilitas memiliki pengaruh terhadap Pengungkapan CSR}




\subsection{Leverage}

Leverage merupakan pemakaian aset serta sumber dana bagi perusahaan yang mempunyai fix cost dan berarti sumber dana yang bersumber dari kreditor sebab mempunyai bunga selaku fix cost yang bertujuan memaksimalkan keuntungan investor secara potensial (Sjahrial 2009). Leverage digunakan sebagai pengukur resiko hutang yang tidak tertagih pada kreditur untuk membiayai aset perusahaan. Kita mampu melihat dan mengukur sejauh apa perusahaan mampu menggunakan pendanaan melalui utang dan mengoptimalkan hutang melalui Rasio (Brigham \& Houston 2010).

Leverage mengukur sebesar apa perusahaan bergantung kepada kreditur. Perusahaan yang memiliki leverage dengan tingkatan yang tinggi akan mendapat perhatian yang lebih dari kreditor, maka perusahaan harus lebih berhati-hati dalam mengelola segala sesuatu. Menurut teori keagenan, teori tersebut menjelaskan bahwasanya perusahaan yang mempunyai tingkat leverage lebih tinggi akan cenderung mengungkapkan infromasi lebih luas, karena keditor akan membutuhkan banyak informasi guna memenuhi kepuasan monitoring terhadap manajemen.

Penelitian mengenai pengaruh leverage terhadap pengungkapan CSR telah dilakukan diantaranya (Rofiqoh \& Priyadi 2016) yaitu leverage mempengaruhi pengungkapan CSR berbeda dengan penelitian yang dilakukan (Herdi \& Erinos 2020) serta penelitian (Cahya \& Sedana 2019) yang menyatakan bahwa leverage tidak mempengaruhi pengungkapan CSR. Dari uraian diatas ditemukan perbedaan hasil penelitian terdahulu, maka dapat ditarik hipotesis.

\section{$\mathrm{H}_{2}$ : Leverage memiliki pengaruh terhadap pengungkapan CSR.}

\subsection{Media Exposure}

Pengawasan publik melalui media terhadap perusahaan dapat berdampak tekanan pada perusahaan terkait kepedulian sosial. Media menjadi sarana penyambung komunikasi antara perusahaan dengan stakeholder. Seiring berkembangnya jaman, perusahaan bukan hanya menggunakan media massa seperti koran dan televisi dalam menyampaikan kegiatan sosial kepada publik, perusahaan juga menggunakan website internet yang diangggap lebih efektif dibanding yang lain. Didukung oleh pengguna internet yang meningkat, zaman sekarang media internet merupakan media yang dianggap efektif (Ratnasari 2012). Pengungkapan melalui media diharapkan memberikan pengaruh positif atau hubungan timbal balik dalam rangka peningkatan nilai perusahaan.

Media exposure memiliki arti segala pengungkapan tanggung jawab jawab sosial yang telah terekpos kepada publik, dalam penyajiannya media bukan hanya memberikan good news terhadap publik, namun media seringkali menyajikan bad news yang dapat menurunkan kepercayaan dari masyarakat. Ini selaras dengan pernyataan teori legitimasi yaitu perusahaan dapat memperoleh legitimasi atau kepercayaan dari publik. 
Penelitian mengenai pengaruh media exposure terhadap pelaporan CSR telah dilakukan beberapa diantaranya (Hasnia \& Rofingatun 2017) sejalan dengan (Pakpahan \& Lasminta 2018) hasil dari penelitian yaitu media exposure mempengaruhi pengungkapan CSR sedangkan penelitian (Widiastuti dkk., 2018) menyatakan bahwa media explosure tidak mempengaruhi pengungkapan CSR. Dari uraian diatas ditemukan perbedaan hasil penelitian, maka dapat ditarik hipotesis:

\section{$\mathrm{H}_{3}$ : Media exposure memiliki pengaruh terhadap pengungkapan CSR.}

\section{Metodologi Penelitian}

\subsection{Jenis Penelitian}

Pada riset ini menggunakan metode penelitian kuantitatif. Penelitian yang menggunakan data berupa angka atau informasi kualitatif yang diubah kedalam angka disebut penelitian kuantitatif (Sugiyono 2016). Riset ini memiliki tujuan mengujikan pengaruh variabel bebas yaitu profitabilitas, leverage, serta media exposure terhadap variabel terikat yaitu CSR (Corporate social Responsibility).

\subsection{Sumber dan Metode Pengumpulan Data}

Penelitian ini menggunakan data sekunder. Laporan atau bahan yang didapatkan dari narasumber secara langsung maupun tidak merupakan data sekunder (Sugiarto 2017). Data sekunder untuk riset ini merupakan data annual report (laporan tahunan) perusahaan sektor pertanian yang terpublikasi periode 2015-2019. Pengumpulan data didapatkan dari pihak ketiga yaitu BEI (Bursa Efek Indonesia) yang bisa diakses melalui situs resminya www.idx.co.id. Data untuk variabel media exposure didapat dari situs internet.

\subsection{Populasi dan Sampel}

Populasi pada riset ini menggunakan semua perusahaan yang tercatat dalam Bursa Efek Indonesia hingga tahun 2019 yakni sejumlah 668 perusahaan. Sampel pada penelitian ini dikumpulkan melalui teknik purposive sampling dengan kriteria tertentu yaitu :

Tabel 3.1

Kriteria Pemilihan Sampel

\begin{tabular}{clc}
\hline No. & \multicolumn{1}{c}{ Kriteria } & Jumlah \\
\hline 1 & $\begin{array}{l}\text { Perusahaan yang terdaftar dalam kelompok } \\
\text { pertanian di BEI tahun 2015-2019 }\end{array}$ & 21 \\
\hline 2 & $\begin{array}{l}\text { Perusahaan yang mempublikasikan laporan } \\
\text { tahunan pada kurun waktu 2015-2019 }\end{array}$ & 15 \\
\hline 3 & $\begin{array}{l}\text { Perusahaan yang mengungkapkan CSR } \\
\text { berturut-turut dalam kurun waktu 2015-2019 }\end{array}$ & 15 \\
\hline Jumlah sampel penelitian pertahun & 15 \\
\hline Jumlah sampel (x5 periode penelitian) & 75 \\
\hline
\end{tabular}




\subsection{Teknik dan Alat analisis data}

Riset ini melalui beberapa tahapan yaitu statistik deskriptif, uji asumsi klasik, regresi linear berganda, serta uji hipotesis dengan memakai program SPSS (Statistical Package for the Sosial Sciences ).

\subsection{Definisi Operasional dan Pengukuran variabel}

\subsubsection{Variabel Dependen}

Variabel dependen penelitian ini menggunakan CSR yang terdapat di laporan tahunan atau CSRI (Corporate social Responibility Index). Pengukuran terhadap pengungkapan tanggung jawab sosial menggunakan content analysis. Content analysis merupakan pembahasan terdalam mengenai informasi tertulis dalam media massa. Pada penelitian ini, pengukuran pengungkapan CSR memakai proksi CSRDI (Corporate social Responsibility Disclosure Index) berlandaskan pada GRI (Global Reporting Initiative) dengan acuan G4. GRI dapat diakses pada situs resminya www.globalreporting.org. GRI-G4 berisi 6 indikator kinerja berupa lingkungan, ekonomi, sosial, hak asasi manusia, tanggung jawab atas produk, masyarakat. Parameter tersebut dibagi kembali menjadi bagian yang lebih kecil menjadi 91 item indikator.

Pengukuran pada penelitian ini dilakukan dengan memberikan skor 1 pada item indikator GRI-G4 yang telah dilaksanakan oleh perusahaan dan memberikan skor 0 apabila item indikator GRI-G4 tersebut tidak dilaksanakan. Total hasil skor tersebut dimaksudkan sebagai pengukuran indeks CSR. Rumus CSRDI:

$$
\operatorname{CSRDI}_{i}=\frac{\sum x_{i}}{n}
$$

Keterangan:

$\begin{array}{lll}\operatorname{CSRDI}_{i} & = & \text { Corporate social Responsibility } \\ \sum X_{i} & = & \text { Total item skor } 1 \\ n & = & \text { Total item indikator pengungkapan CSR }\end{array}$

\subsubsection{Variabel Independen}

\subsubsection{Profitabilitas}

Pada penelitian ini, profitabilitas dikur dengan ROA (Return Of Asset). ROA menunjukkan seberapa efektif perusahaan dapat mengelola aktiva guna peningkatan laba. Perusahaan yang mampu menghasilkan laba dalam aktivitas operasi dari total aset yang digunakan ditunjukan oleh ROA yang positif, sedangkan perusahaan yang memperoleh 
kerugian dalam aktivitas operasi dari total aset yang digunakan ditunjukan oleh ROA. Berikut rumus untuk menghitung $\mathrm{ROA}$ :

$$
\mathrm{ROA}=\frac{\text { Laba Bersih }}{\text { Total Asset }} \times 100 \%
$$

\subsubsection{Leverage}

Rasio DER (Debt to Equity Ratio) pada riset ini sebagai pengukur leverage. Total dana yang disediakan kreditur dengan pemilik perusahaan juga dapat dilihat dari rasio DER (Kasmir 2014). Berikut rumus penghitungan DER:

$$
\text { DER }=\frac{\text { Total Utang }}{\text { Total Modal }} \times 100 \%
$$

\subsubsection{Media Exposure}

Pada peneltian ini, media eksposure diukur berdasarkan publikasi kegiatan CSR pada media online. Media online yang digunakan pada penelitian ini menggunakan dua surat kabar online di indonesia yaitu Kompas mewakili berita nasional dan tribunnews mewakili berita lokal pada periode selama 1 Januari 2015 hingga 31 Desember 2019. Pencarian artikel pada dua surat kabar dilakukan dengan memanfaatkan fasilitas pencarian. Artikel yang akan digunakan berupa penghargaan dan pengawasan tanggung jawab sosial dari publik. Pengukuran dilakukan dengan memberikan skor 1 apabila terdapat artikel kegiatan CSR dan memberikan skor 0 apabila tidak ditemukan artikel kegiatan CSR dalam surat kabar online.

\subsection{Model Empiris Penelitian}

Penelitian ini menggunakan analisis regresi linear berganda. Persamaan regresi yang dipakai untuk menguji hipotesis tersebut adalah:

$$
Y=\beta_{0}+\beta_{1} X_{1}+\beta_{2} X_{2}+\beta_{3} X_{3}+e
$$

Keterangan:

$\mathrm{Y} \quad=\quad \operatorname{CSR}$ (Corporate social Responsibility)

$\beta_{0}=$ Konstanta

$\beta_{1}, \beta_{2,} \beta_{3}=\quad$ Koefisien regresi

$X_{1}=$ ROA (Profitabilitas)

$X_{2}=\operatorname{DER}($ Leverage)

$X_{3}=\operatorname{ME}$ (Media Exposure)

$\mathrm{e}=$ error 


\section{Hasil dan Pembahasan}

\section{1 Hasil Uji Statistik deskriptif}

Pada penelitian ini Statistik deskriptif digunakan untuk mendiskripsikan ataupun menjelaskan data yang telah terkumpul. Statistik deskriptif memperlihatkan sebuah gambaran data yang dapat dilihat dari nilai standar deviasi, rata-rata (mean), maksimum, varian,minimum. (Ghozali 2011).

Tabel 4.1

Hasil Output Statistik Deskriptif Statistik Deskriptif

\begin{tabular}{lccccc}
\hline & N & Minimal & Maksimal & Rata-rata & $\begin{array}{c}\text { Std. } \\
\text { Deviasi }\end{array}$ \\
\hline ROA & 75 & $-58,25$ & 9,90 &,- 8667 & 10,43743 \\
\hline DER & 75 & $-4595,94$ & 1015,80 & 7,8004 & 584,63433 \\
\hline ME & 75 &, 00 & 1,00 &, 1333 &, 34222 \\
\hline CSR & 75 &, 10 &, 70 &, 3057 &, 16118 \\
\hline Valid N (listwise) & 75 & & & & \\
\hline \multicolumn{5}{l}{ Sumber : data diolah, 2020 }
\end{tabular}

Berdasarkan Tabel.2 diketahui bahwasanya nilai CSR yang tinggi pada tabel mempunyai arti yakni CSR lebih banyak diungkapkan. Pengungkapan CSR menunjukan score maksimun 0,70 serta score minimun 0,10. Berata-rata (mean) 0,3057 serta standar deviasi 0,16118 . Variabel profitabilitas diukur dengan ROA menunjukan nilai maksimum sebesar 9,90 serta nilai minimum sejumlah - 58,25. Berata-rata $-0,8667$ serta standar deviasi 10,43743. Variabel leverage diukur dengan DER menunjukkan nilai maksimum sebesar 1015,80 dan nilai minimun $-4595,94$. Berata-rata 7,8004 serta standar deviasi sebesar 584,63433. Variabel media exposure menunjukkan score maksimum 1,00 serta score minimum 0,00. Berata-rata 1,333 serta standar deviasi 0,34222.

\subsection{Uji Hipotesis}

4.2.1 Analisis regresi linear berganda

Tabel 4.5

Output Regresi Linear Berganda

Coefficients $^{a}$

\begin{tabular}{cc}
\hline $\mathrm{B}$ & Std. Error \\
\hline, 930 &, 082 \\
\hline, 008 &, 007 \\
\hline, 000 &, 001 \\
\hline, 171 &, 056 \\
\hline
\end{tabular}


Variabel dependen pada uji regresi linear berganda ini adalah Profitabilitas (ROA), Leverage (DER), Media Exposure (ME), maka model regresi yaitu :

$Y=0,930+008 x_{1}+0,000 x_{2}+0,171 x_{3}+e$

\subsubsection{Uji Koefisien Determinasi $\left(\boldsymbol{R}^{2}\right)$}

Uji Koefisien Determinasi mengetahui sejauh apa variabel dependen mampu menerangkan variasi variabel dependen. Apabila besaran nilai koefisien determinasi rendah maka variabel independen hanya mampu menerangkan variasi variabel secara terbatas (Ghozali 2016)

\begin{tabular}{lrr} 
& \multicolumn{2}{c}{$\begin{array}{c}\text { Tabel } 4.6 \\
\text { Hasil uji } \mathbf{R}^{2} \\
\text { Model Summary }\end{array}$} \\
\hline $\mathrm{R}$ & R Square & $\begin{array}{c}\text { Adjusted R } \\
\text { Square }\end{array}$ \\
\hline, $414^{\mathrm{a}}$ &, 171 &, 136 \\
\hline
\end{tabular}

Berdasarkan Tabel.7 pada kolom adjusted $\mathrm{R}$ Square menunjukan 0,136 yang berarti bahwasanya variabel Profitabilitas, Leverage, serta Media Exposure mempengaruhi sebesar $13,6 \%$ atas pengungkapan CSR dan sisa $86,4 \%$ dipengaruhi oleh variabel tak terduga lainya.

\subsubsection{Uji F}

Uji F agar mengetahui apakah Profitabilitas, Leverage, Media Exposure tepat digunakan dan secara bersama mempunyai pengaruh terhadap CSR.

\begin{tabular}{cc}
\multicolumn{2}{c}{$\begin{array}{c}\text { Tabel } 4.7 \\
\text { Hasil uji F } \\
\text { ANOVA }\end{array}$} \\
\hline F & Sig. \\
\hline 4,884 &, $004^{\mathrm{a}}$ \\
\hline
\end{tabular}

Berdasarkan Tabel.8 pengujian terhadap $\mathrm{F}$ dapat dilihat pada kolom $\mathrm{F}$ hitung sebesar 4,884 dengan signifikasi 0,004 yakni lebih kecil dari 0,05, sehingga dengan demikian hasil uji $F$ ini memberikan makna bahwa setidaknya salah satu variabel bebas yang diteliti (Profitabilitas, Leverage, Media Exposure) memiliki pengaruh signifikan terhadap variabel dependen yang diteliti. 


\subsubsection{Uji T}

Dengan melihat kolom Sig maka dilakukan uji T untuk mengetahui apakah variabel independen berpengaruh semata-mata terhadap variabel dependen. Apabila kolom Sig menunjukan nilai < 0,05 maka variabel dependen mempengaruhi variabel independen. Sebaliknya, jika kolom Sig menunjukan nilai > 0,05 maka variabel dependen tidak akan mempengaruhi variabel independen.

\begin{tabular}{|c|c|}
\hline$t$ & Sig. \\
\hline 11,411 & ,000 \\
\hline 1,228 & ,224 \\
\hline,- 309 & ,758 \\
\hline 3,038 & 003, \\
\hline
\end{tabular}

Berdasarkan Tabel. Analisis pada ROA atau profitabilitas didapat dari nilai signifikasi sebesar 0,224 dan nilai koefisian regresi positif sebesar 1,228. Nilai signifikan > 0,05 menunjukan jika $\mathrm{H}_{1}$ ditolak yaitu profitabilitas tidak mempengaruhi pengungkapan CSR secara signifikan.

Hasil analisis variabel leverage (DER) didapat nilai signifikasi sebesar 0,758 dengan nilai koefsien regresi bernilai negatif sebesar $-0,309$. Nilai signifikan $>0,05$ menunjukan bahwa $\mathrm{H}_{2}$ ditolak yakni leverage mempengaruhi pengungkapan CSR secara signikan.

Hasil analisis pada ME atau Media Exposure didapat nilai signifikasi sebesar 0,003 dengan nilai koefisien regresi bernilai positif sebesar 3,038. Nilai signifikasi < 0,05 menunjukan bahwa $\mathrm{H}_{3}$ diterima yakni media exposure mempengaruhi pengungkapan CSR secara signifikan.

Hipotesis pertama $\left(\mathrm{H}_{1}\right)$ dalam riset ini yakni profitabilitas dinyatakan ditolak. Penelitian ini mempunyai hasil yang menunjukan profitabilitas tidak mempengaruhi pengungkapan CSR dengan nilai siginifikasi sebesar 0,224 dan besaran nilai koefisien regresi positif 1,228 dimana nilai signifikasi lebih besar dari 0,05 artinya jika kenaikan profitabilitas suatu industri tidak mempengaruhi pengungkapan CSR. Perusahaan dengan tingkatan profitabilitas tinggi bukan berarti mereka banyak melakukan CSR, hal ini dikarenakan laba suatu industri hanya difokuskan untuk kegiatan operasi perusahaan, sejalan dengan teori (Sembiring 2005) yang berisi bahwa manajemen lebih fokus pada pengungkapan informasi keuangan dan memungkinan untuk menghindari hal menutup informasi keuangan seperti CSR. Hasil ini searah dengan riset oleh (Rofiqoh and Priyadi 2016) yang memilki hasil profitabilitas tidak mempengaruhi pengungkapan CSR. 
Hipotesis kedua $\left(\mathrm{H}_{2}\right)$ dalam riset ini yakni leverage dinyatakan ditolak. Hasil penelitian yang sudah dilakukan membuktikan pengungkapan CSR tidak dipengaruhi oleh leverage dengan nilai siginifikasi sebesar 0,758 dengan nilai koefisien regresi negatif sebesar- 0,309 dimana nilai signifikasi lebih dari 0,05 berarti jika tingkat leverage yang dimiliki sesuatu industri tidak mempengaruhi pengungkapan CSR. Tingkatan leverage sesuatu industri tidak mempengaruhi tinggi rendahnya pengungkapan CSR, hal ini disebabkan industri hendak berupaya menaikkan laba dengan mengurangi biaya- biaya operasional. Hal ini juga berlawanan dengan teori keagenan yang menerangkan jika industri dengan tigkat leverage besar akan semakin banyak menyampaikan informasi lebih perinci. Hasil riset ini selaras dengan riset terhadap leverage yang sudah dilakukan oleh (Herdi and Erinos 2020) yang melaporkan jika leverage tidak mempengaruhi pengungkapan CSR.

Hipotesis ketiga $\left(\mathrm{H}_{3}\right)$ pada riset ini dinyatakan diterima yakni variabel media exposure menurut hasil uji analisis regresi linear berganda yang sudah peneliti lakukan. Hasil peneltian membuktikan media exposure mempengaruhi pengungkapan CSR dengan nilai siginifikasi sebesar 0, 003 dengan nilai koefisien regresi positif sebesar 3,038. dimana nilai signifikasi lebih dari 0,05 yang berarti jika semakin banyaknya pengungkapan media terhadap aktivitas CSR suatu industri maka akan mempengaruhi pengungkapan CSR yang tinggi pula. Pemberitaan media terhadap kegiatan CSR suatu perusahaan mempengaruhi perusahaan mengungkapkan CSR lebih tinggi lagi. Sesuai dengan teori pensignalan, suatu perusahaan akan terus memberikan informasi positif kepada masyarakat agar perusahaan mempunyai citra positif dimata publik. Hasil riset sama dilakukan oleh (Hasnia and Rofingatun 2017) dengan (Pakpahan and Lasminta 2018) yang melaporkan media exposure mempengaruhi pengungkapan CSR.

\section{Kesimpulan, Keterbatasan, dan Saran}

Kesimpulan yang bisa ditarik berdasarkan riset ini yaitu profitabilitas dan leverage tidak mempengaruhi pengungkapan CSR serta pengungkapan media mempengaruhi pengungkapan CSR. Keterbatasn penelitian dalam penilaian CSR hanya terbatas pada 91 indikator GRI-G4 dan pengukuran media exposure hanya terbatas pada dua surat kabar online yaitu kompas dan tribunnews. Bagi peneliti selanjutnya agar menggunakan standar pengukuran CSR terbaru dan lebih banyak menggunakan surat kabar online untuk mengumpulkan data media exposure. 


\section{Daftar Pustaka}

Brigham, Eungene F., \& Jouel F. Houston. 2010. Dasar-Dasar Manajemen Keuangan. 11th ed. Jakarta: Salemba Empat.

Brigham, Eungene F., \& Jouel F. Houston. 2011. Dasar-Dasar Manajemen Keuangan Buku 2. Jakarta: Salemba Empat.

Cahya, Dewi Putu Ayu, \& Ida Bagus Panji Sedana. 2019. "Pengaruh Profitabilitas, Ukuran Perusahaan, Dan Leverage Terhadap Pengungkapan Corporate Social Responsibility." EJurnal Managemen 8(11):6618-37.

Fahmi, Irham. 2012. Analisis Kinerja Keuangan. Bandung: Alfabeta.

Fakhrudin, Hendi M. 2008. Istilah Pasar Modal A-Z. Jakarta: Gramedia.

Fuad, Amelinda Vindrayani. 2017. "Health Agen Award Sebagai Corporate Social Responsibility PT. Nutrifood Indonesia." Jurnal Profesi Humas 2(1):37-44.

Ghozali, Imam. 2011. Aplikasi Analisis Multivariate Dengan Program SPSS. Semarang: Badan Penerbit Universitas Diponegoro.

Ghozali, Imam. 2013. Aplikasi Analisis Multivariate Dengan Program IBM SPSS 21 Update PLS Regresi. Semarang: Badan Penerbit Universitas Diponegoro.

Ghozali, Imam. 2016. Aplikasi Analisis Multivariate Dengan Program IBM SPSS 23. Semarang: Badan Penerbit Universitas Diponegoro.

Gray, Owen, \& Maunders. 1988. "Corporate Social Reporting: Emerging Trends In Accountability And The Social Contract." Accounting, Auditing \& Accountability Journal $1: 6-20$.

Hadi, Nor. 2011. Corporate Social Responsibility. Yogyakarta: Graha Ilmu.

Hanafiah, Junaidi. 2020. "Sungai Tercemar Limbah Masyarakat Nagan Raya Laporkan Tiga Perusahaan Sawit Ke Dinas Lingkungan Hidup." Www.Mongabay.Co.ld. Retrieved December 19, 2020 (https://www.mongabay.co.id/2020/08/22/sungai-tercemar-limbahmasyarakat-nagan-raya-laporkan-tiga-perusahaan-sawit-ke-dinas-lingkungan-hidup/).

Hasnia, \& Siti Rofingatun. 2017. "Pengaruh Profitabilitas, Likuiditas, Groeth Dan Media Exposure Terhadap Pngungkapan Tanggung Jawab Sosial Perusahaan." JURNAL Akuntansi \& Keuangan Daerah 12(1):56-71.

Herdi, Fitri, \& NR Erinos. 2020. "Pengaruh Profitabilitas, Leverage, Dan Komposisi Dewan Komisaris." Jurnal Eksplorasi Akuntans 2(1):2428-44.

Ikatan Akuntansi Indonesia. 2012. Standar Akuntansi Keuangan. Jakarta.

Jensen, M., \& W. Mecking. 1976. "Theory of The Firm: Managerial Behaviour, Agency Costs and Ownership Structure." Financial Ecomomics 3 No.4:305-60.

Kasmir. 2014. Analisis Laporan Keuangan. Jakarta: PT Raja Grafindo Persada. 
Mandaika, Yusi, \& Hasan Salim. 2015. "Pengaruh Ukuran Perusahaan, Kinerja Keuangan, Tipe Industri Dan Financial Leverage Terhadap Pengungkapan Corporate Social Responsibility." Jurnal Akuntans Ekonomi 2:181-201.

Mardikato, Totok. 2014. CSR (Corporate Social Responsibility) (Tanggung Jawab Sosial Korporasi). Bandung: Alfabeta.

Maulana, Atlas. 2019. "Puluhan Perusahaan Sawit Diduga Tidak Realisasikan Csr." $\begin{array}{llll}\text { Www.Antaranews.Com. } & \text { Retrieved } & \text { October } & 16,\end{array}$ (https://www.antaranews.com/berita/799740/puluhan-perusahaan-sawit-diduga-tidakrealisasikan-csr).

Pakpahan, Yunus, \& Lasminta. 2018. "Analisis Pengaruh Profitabilitas, Ukuran Perusahaan, Ukuran Dewan Komisaris, Dan Media Exposure Terhadap Pengungkapan Tanggung Jawab Sosial." Jurnal Akuntans 18(2):197-218.

Peraturan Pemerintah RI. 2012. Peraturan Pemerintah No.47 Tentang Tanggung Jawab Sosial Dan Lingkungan Perseroan Terbatas.

Priyatno, Duwi. 2014. SPSS 22 Pengolahan Data Terpraktis. Yoyakarta: Penerbit Andi.

Ratnasari, Diar. 2012. "Analisis Faktor-Faktor Yang Mempengaruhi Perataan Laba." Jurnal Universitas Diponegoro.

Rofiqoh, Esti, \& Maswar Patuh Priyadi. 2016. "Pengaruh Profitabilitas, Leverage, Dan Ukuran Perusahaan Terhadap Pengungkapan Tanggung Jawab Sosial Perusahaan." Jurnal IImu Dan Riset Akuntansi 1-18.

Ruroh, Ivon Nurmas, \& Sri Wahjuni Latifah. 2018. "Pengaruh Profitabilitas, Leverage, Ukuran Perusahaan, Dan Risk Minimation." Jurnal Akademi Akuntansi 1(11):42-53.

Sari, Rizkia Anggita. 2012. "Pengaruh Karakteristik Perusahaan Terhadap Corporate Social Responsibility Disclosure Pada Perusahaan Manufaktur Yang Terdaftar Di Bursa Efek Indonesia." Riset Akuntansi Dan Manajemen 1 No. 2:124-40.

Sartono, Agus. 2010. Managemen Keuangan Teori Dan Aplikasi. Yogyakarta: BPFE.

Sembiring. 2005. Karakteristik Perusahaan Dan Pengungkapan Tanggung Jawab Sosial. Solo.

Sharpe, William F. 1997. Portfolio: Theory \& Capital Market. New York: McGraw-Hill.

Sjahrial, Dermawan. 2009. Pengantar Manajemen Keuangan. Jakarta: Mitra Wacana Media.

Sugiarto. 2017. Metodologi Penelitian Bisnis. Yogyakarta: ANDI.

Sugiyono. 2016. Metode Penelitian Kuantitatif, Kualitatif, Dan R\&D. Bandung: Alfabeta.

Supriyono, R. A. 2018. Akuntansi Keprilakuan. Gajah Mada University.

Undang-Undang. 2009. Undang-Undang Republlik Indonesia. Jakarta.

Wibowo, Imam. 2014. "Dampak Pengungkapan Sustainability Report Terhadap Kinerja Keuangan Dan Kinerja Pasar Perusahaan." Simposium Naional Akuntansi XVII Mataram. Widiastuti, Harjanti, Evy Rahman Utami, \& Ridi Handoko. 2018. "Pengaruh Ukuran Perusahaan, 
Tipe Indusutri, Growth, Dan Media Exposure Terhadap Pengungkapan Tanggung Jawab Sosial Perusahaan." Akuntansi Dan Keuangan Indonesia 107-17. 